\title{
Examining obligations to society for QS Stars best ranked universities in social responsibility
}

\author{
Carmen PĂUNESCU \\ Bucharest University of Economic Studies, UNESCO Department for Business \\ Administration, Bucharest, Romania \\ carmen.paunescu@ase.ro
}

Denisa DRĂGAN (GILMEANU)

Bucharest University of Economic Studies, Doctoral School for Business Administration, Bucharest, Romania

\author{
Oana GĂUC̆ \\ Bucharest University of Economic Studies, Doctoral School for Business Administration, \\ Bucharest, Romania
}

\begin{abstract}
Developing the local, regional, even national communities is often central to a university's mission. This is a two-way process and both society and university itself should benefit from this collaboration. Universities around the world have been in the past decades required to leave their ivory tower and to become more involved in addressing the needs of the society and thus more relevant for the communities which they serve. They are expected to take a leadership role in implementation of the required change by contributing to community development through knowledge, innovations, skills and jobs. By taking a leading role in society and continuously innovating, universities will support communities with achieving a sustainable growth and therefore will contribute to increasing the well-being of society at large. The current paper aims to assess the university obligations to society by analyzing 27 universities around the world best ranked in social responsibility according to QS Stars University Rating 2016. In the paper, we discuss the extent to which different attributes of the university social responsibility are reflected among the initiatives and projects run by the universities included in the study. Also, an exploratory factor analysis was employed to identify underlying variables that explain the pattern of correlations between university social responsibility initiatives. Following the QS Stars methodology, the dimensions used to evaluate social responsibility of sampled universities included: community investment and development, social work and disaster relief, regional human capital development, and environmental impact. The results show that the level of involvement in social responsibility actions is high for all the universities included in the study. Also, the types of initiatives vary in terms of nature, intensity and impact for each one of the dimensions analyzed. Our research findings offer useful insights for both universities' leaders and community developers in their joint-efforts to develop and grow a prosperous community.
\end{abstract}

Keywords: social responsibility, university ranking, community development, QS Stars University Ratings, factor analysis.

Please cite the article as follows: Păunescu, C., Drăgan (Gilmeanu), D. and Găucă, O. (2017), "Examining obligations to society for QS Stars best ranked universities in social responsibility", Management \& Marketing. Challenges for the Knowledge Society, Vol. 12, No. 4, pp. 551-570. DOI: 10.1515/mmcks-2017-0033. 


\section{Introduction}

Education is regarded as a means through which individuals can improve their quality of life, while also contributing to the development of society. For these reasons education has been considered a public good to which all individuals deserve unencumbered access and which contribute to a wide extent to economic and social development. During time, universities have always been engines for the growth of national economies. In multiple roles they play, they tried continuously to align their offerings with the evolving expectations of their students and keep the pace with environmental changes (Pucciarelli and Kaplan, 2016). In addition, universities also assumed an active role in the communities which they served and acted as a binder between academic and community actors, necessary to contribute to the society development (Irazábal et al., 2015; Păunescu, 2017). Like any other organization, universities are expected to play an important role as a change agent necessary to feed community development through knowledge, skills and jobs, helping them also to develop their own way of sustainable growth. By taking a leading role in changing society, universities can contribute decisively to implementation of needed change.

Social responsibility is generally defined in the literature as the interest of an individual or organization to assume responsibility of the consequences of his/its actions upon the community, other that his/its immediate circle (Klekovski et al., 2009). It should be a primary concern of each individual or organization. Moreover, it is not the general responsibility that usually lacks, but it is the understanding of the power each individual has to make a change and that individual's ability to gather resources for the change to happen. For a university, social responsibility translates mainly into the desire to invest in community and contribute to its development. Some scholars define community development as a process in which various stakeholders unite their forces to improve living conditions and the wellbeing of their community (Checkoway, 1995). In a community-driven educational environment, universities and society share common goals and values, which help them develop in the same direction and on common grounds to generate the needed change.

The current paper aims to assess the nature and types of university obligations to society by analyzing 27 world universities best ranked in social responsibility according to QS Stars University Ratings 2016. In the paper we discussed the extent to which different attributes of the university social responsibility are reflected among the initiatives and projects run by the universities included in our study. A factor analysis was employed to identify underlying variables that explain the pattern of correlations between the university social responsibility initiatives. The paper starts with a literature review of the university's perspective on social responsibility. Then it explains the methodology used. Finally, an exploratory factor analysis was conducted on variables describing social responsibility in sample universities and conclusions were drawn based on results.

\section{Literature review}

\section{University's perspective on social responsibility}

The discussion of the role played by social responsibility in higher education is highly relevant in the current social and economic context which has given rise to questions regarding a necessary reframing of the social role of higher education institutions Vol. 12, No.4, Winter, pp. 551-570 ISSN 1842-0206 | Management \& Marketing. Challenges for the Knowledge Society 
(Vasile et al., 2015; Păunescu and Cantaragiu, 2015). Universities around the world have been in the past decades required to leave their ivory tower and to become more involved in addressing the needs of the society, and thus more relevant for the communities which they serve.

Over the time, the higher education institutions have striven to maintain a good balance between their traditional mission of liberal education and their new mission of direct contributors to economic and social development. The resulting paradigm sees higher education institutions as catalysts for social innovation as their main role is to help overcome social inertia and to advocate, while also providing the means, for a move away from the status quo and its inherent social problems (Janiunaite and Gudaityte, 2007). The most recent changes in the governance systems of higher education institutions are related to an increased autonomy from state authority. The role of the state has changed because it has become more focused on ex post control rather than on ex ante control. This comes as a result of an increased reliance on quality performance measurements and institutional outputs (such as research articles, citations, and graduates) and outcomes (regional and local projects) as a basis for funding allocation instead of relying on the inputs (such as number of students) (De Boer et al., 2007).

Nowadays, there is an increased pressure to include into the university governance structures representatives of both internal stakeholders who previously lacked voice and representation (such as the students) and external stakeholders who have recently gained increased legitimacy in regards to their more active role in decision-making processes (business, NGOs and other representatives of relevant communities). The main assumption which underlies the opening of the governance structures to various non-traditional groups is that this change will help higher education institutions achieve higher responsiveness and accountability to their stakeholders' needs and interests (Amaral and Magalhães, 2002; Ercsey, 2017). This has been linked to the notion of shared governance (Sporn, 1999) and social responsibility, which emphasizes the need for achieving consensus in regards to organizational goals and extended accountability. Social responsibility in education is not as popular and visible as in other fields such as health, rural and urban development or economic development. However, there are clear signs that the paradigm is quickly gaining momentum. As such, the future of education will most probably be linked to its ability to accommodate the process of managing obligations to society.

It is widely acknowledged that higher education has a triple mission (De Boer et al., 2007; Jongbloed et al., 2008; Dudian, 2011; Irazábal et al., 2015): to provide education, to advance research and to demonstrate commitment to community development. Laredo (2007) identified three main functions corresponding to the three missions the higher education has: mass tertiary education (focused on bachelor degree), professional specialized higher education and research (focused on professional master degree and having problem solving as core activity) and academic training and research (focus on PhD degree and articles as outputs). Thus, he provides a new lens for analyzing links with the external environment and placing education and research on a similar level of importance. 
Community development as the third mission of the university has been central in higher education discourses for many years (Benneworth and Sanderson, 2009; Farrar and Taylor, 2009; Kruss, 2012). Some scholars view the concept as a university's service to the community through knowledge dissemination (Weerts and Sandmann, 2008). Other researchers regard the third mission as the ability of the university to align its activity to economic development (Etzkowitz and Viale, 2010), or having its faculty engaged in academic entrepreneurship (D'Este and Patel, 2007). Therefore, community investment is regarded as a part of the entrepreneurial initiative of the universities that can bring extra income during times of financial difficulty (Clark, 1998). Philpott et al. (2011) found an unbalanced split between the disciplines within an entrepreneurial university, making the third mission being perceived as "a threat to the purpose of a university" (p. 168). They underline once more the pressure put on the academics in order to develop entrepreneurial activities in the detriment of research and education, therefore possibly contributing to economic development on the expense of the contributions to the other two. Moreover, Laredo (2007) questions the fact that this third mission has been linked to the entrepreneurial dimension of the university and not to its ability of generating new research projects or new teaching curricula. In fighting the shortage of funding of research, universities requesting the funds through entrepreneurial applications could significantly impact the production of knowledge that leads to better results for both university and community (Callon and Rabeharisoa, 2003).

Over time, the term of community engagement and development has replaced various other different terminologies used for the same scope, such as outreach, extension or service (Bender, 2008; Bernardo et al., 2012). With the new competition that is faster increasing, universities themselves had to invest more in building connections with the communities, promoting a more caring social image, and supplying constantly added value to all their stakeholders (Boyle and Silver, 2005; Păunescu et al., 2017). Formal collaborations between businesses, community groups and universities to promote economic and social development have increased substantially over the last decade. However, researches on community-campus partnerships acknowledged a gap in regards to real understanding of community experiences (Afshar, 2005). They put a strong emphasis on mutual beneficial relations that the universities can develop with the outside world with the purpose of knowledge creation and exchange (Muller and Subotzky, 2001; Dima et al., 2013; Mtawa et al., 2016).

Community-academic partnerships and other forms of university engagement in community can be difficult and time consuming. There are many reports exploring the dynamics of such developments (e.g., Hammersley, 2013). Existing literature, however, does not include systematic assessments of how academia actually involves community in their research and projects, what works, what doesn't, and how the types and objectives of the projects influence how communities are involved and will develop (Sullivan et al., 2001; Goldberg-Freeman et al., 2010). Therefore, engagement from a university's perspective translates into everything that is important for the community: from change of mentalities, attitudes and ways in which things are done, up to knowledge creation or skills development through collaboration between the social, economic and academic actors. University community engagement comes

Vol. 12, No. 4, Winter, pp. 551-570 ISSN 1842-0206 | Management \& Marketing. Challenges for the Knowledge Society 
through the students, academic faculties and other partner institutions as a whole and takes various forms, like solutions, information, knowledge, research, feedback, technical assistance and support (Bernardo, 2012; Păunescu et al., 2017). No real social problem can be solved or even understood without academia and community working together.

\section{Methodology \\ Research objectives}

The paper objectives are two folded: (1) understanding the type of social responsibility initiatives in which the universities around the world engage and invest; (2) determining the underlying components or factors that explain the patterns of correlations within a set of observed variables, in our case the social responsibility initiatives. The paper also aims to determine the extent to which an intensive work in different areas of social responsibility contributes to a higher ranking in social responsibility and successively to a better overall ranking of university.

Therefore, based on the literature reviewed, we hypothesized the following:

H1: The more prevalent the social responsibility initiatives of universities for each dimension of analysis, the higher the university rating in social responsibility and the better the university overall ranking.

H2: There are specific underlying components or factors that can produce correlation amongst the different types of social responsibility activities of a university and therefore that can determine a higher university rating in social responsibility.

The present research relied on the QS Stars University Rating 2016 (https://www.topuniversities.com/qs-stars) database. QS Stars is a rating system which allows students, academics or institutions themselves to assess universities based on a wide range of qualities. There are eleven criteria and over 50 different indicators that form the basis of QS Stars University Ratings: research, teaching, employability, internationalization, facilities, online and distance learning, social responsibility, innovation, arts and culture, inclusiveness, specialist criteria. Higher education institutions worldwide, which demonstrate commitment and performance in relation to each one of those criteria, are evaluated on an annual basis and successfully awarded between one and 5+ stars over five wider fields, as well as an overall rating. In the paper we analyze one of these wider fields, namely the university commitment and obligations to society hereinafter referred to in the paper as social responsibility. For the purpose of QS Stars University Ratings the university's social responsibility is measured using four dimensions: (a) Community investment and development, understood as benefits (both financial and intangible gains) gained by communities served by university; (b) Charity work and disaster relief, understood as interest in supporting charities and social cause campaigns, interest in volunteering, disaster relief campaigns, etc.; (c) Regional human capital development, measured by graduate employability rate within the region or proportion of the students admitted from the region, and (d) Environmental impact, measured by the nature and intensity of programs that address needs for energy conservation, water conservation, waste minimization, green transportation, recycling, etc. These dimensions further made the 
object of the current research with the purpose of understanding the types of social responsibility initiatives which a university engages in. They were analyzed using an exploratory factor analysis.

\section{Data}

According to QS Stars University Ratings 2016, there are 195 universities listed in overall ranking (OR), 88 universities ranked in social responsibility (SR), 171 in employment (E) and 155 in inclusiveness (I) (Table 1). Also, 46.59\% (n=41) of the universities listed in overall ranking are 5 stars universities in social responsibility, $57.89 \%(n=99)$ are 5 stars universities in employment and $78.70 \%(n=122)$ in inclusiveness. While social responsibility measures how seriously a university takes its obligations to society by investing in the local communities and addressing global issues, employment encompasses graduates' work-readiness and inclusiveness looks at university commitment to extending access to higher education.

Table 1. University ratings according to QS Stars University Ratings 2016

\begin{tabular}{|l|ccccccc|}
\hline \multirow{2}{*}{ Criteria } & \multicolumn{7}{c|}{ No. of universities in each star category } \\
\cline { 2 - 9 } & Total & 5 stars+ & 5 stars & 4 stars & 3 stars & 2 stars & 1 star \\
\hline Overall ranking (OR) & 195 & 17 & 54 & 39 & 59 & 25 & 1 \\
\hline Social responsibility (SR) & 88 & - & 41 & 9 & 20 & 7 & 11 \\
\hline Employment (E) & 171 & - & 99 & 29 & 24 & 16 & 3 \\
\hline Inclusiveness (I) & 155 & - & 122 & 16 & 14 & 2 & 1 \\
\hline
\end{tabular}

Source: Processed based on QS Stars University Ratings 2016. [online] Available at: https://www.topuniversities.com/qs-stars.

Based on the correlations identified between those rankings (for example, universities' rating in each one of the social responsibility, employment and inclusiveness rankings), we extracted a list of 27 universities around the world, which are further studied in the paper (Table 2). The selection was based on four core criteria: rating mainly as 5 star university in social responsibility, geographical representation of university worldwide and its presence in both employment and inclusiveness QS Stars rankings. Those criteria were meant to open us the opportunity to access a large and rich pool of best practices on social responsibility in universities worldwide. To understand the types of social responsibility initiatives in which the sample universities engage and invest, we looked on their official websites and identified a series of examples of social responsibility actions in connection with each one of the four dimensions of analysis. The period of data collection extended from October 2016 up to January 2017.

\section{Results and discussion Preliminary findings}

A preliminary analysis of our data revealed that out of the 27 universities extracted for analysis, $92.59 \%(n=25)$ are rated as 5 stars in social responsibility, $85.18 \%$ $(n=23)$ are rated as 5 stars in employment, and 66.66\% (n=18) are 5 stars in inclusiveness. Out of those universities only $37.03 \%(n=10)$ are rated in the overall ranking. This leads us to the observation that a high ranking in social responsibility is positively correlated with a high ranking in employability and a good ranking in 
inclusiveness, but not of the same tie. Moreover, there is a weak positive correlation between ranking in social responsibility and overall ranking of universities, which means that other criteria have a stronger contribution to the universities rating in the global ranking (Daraio et al., 2015; Păunescu et al., 2017).

\section{Analysis of social responsibility initiatives Community development}

Community development activities are those that embrace the idea of "scholarship of engagement" (Boyer, 1996) in which the local, regional, national and international community is considered as an active stakeholder in the life of the university. At the top QS Stars universities included in our study these activities are highly varied both in terms of the external stakeholders involved (youth, employees, local NGOs, businesses, the general public, etc.), the nature of the services provided by the university (research, professional services, opening up facilities to the general public, etc.) and the temporality of the engagement (long-term, short-term, periodical, episodic, etc.). Based on these characteristics there are five different categories of activities prevalent in our studied universities: professional community service, community-based research, support for cultural heritage, support for local business development, and educational programs for the local community (Table 2).

Universities which have law or medical faculties usually provide professional community services through their hospitals and clinics where the local community can access paid or free professional advice/services. For example, Universitas Islam Indonesia (www.uii.ac.id) has a special agency affiliated with the law school through which it improves the access to justice for disadvantaged people that belong to communities which are economically, socially and politically marginalized.

Community-based research refers to research projects in which the community's needs represent what leads the research initiative and in which the community is an active participant in the research process. The most prominent example for this type of community development initiative comes from the University College Cork (www.ucc.ie) in Ireland which has set up the Community-Academic Research Links initiative through which it allows local non-profit organization to join research projects by proposing research topics and working with students in order to advance their programs for the community through the conduct of scientific research.

Universities included in our study also provide support for cultural heritage and modern arts. For example, the Department of Archeology at the University College Cork (www.ucc.ie) has a long tradition in offering support on heritage matters to local organizations, schools and communities and excavate archeological sites, restore monuments and provide access to scholarly knowledge and archives with the aim of promoting a greater understanding of the cultural heritage in Ireland. Moreover, universities also act as repositories of cultural heritage and they open up their resources to the general public as in the case of the Harvard Film Archive (hcl.harvard.edu/hfa). Universities also support the development of local businesses which have a direct social impact. For example, the Universidade Anhemi Morumbi (portal.anhembi.br) from Brazil is partner in a special program that fosters local social entrepreneurship by offering Brazilian social enterprises public recognition, funding and training in order to develop their activities and grow.

Vol. 12, No.4,Winter, pp. 551-570 ISSN 1842-0206 | Management \& Marketing. Challenges for the Knowledge Society 


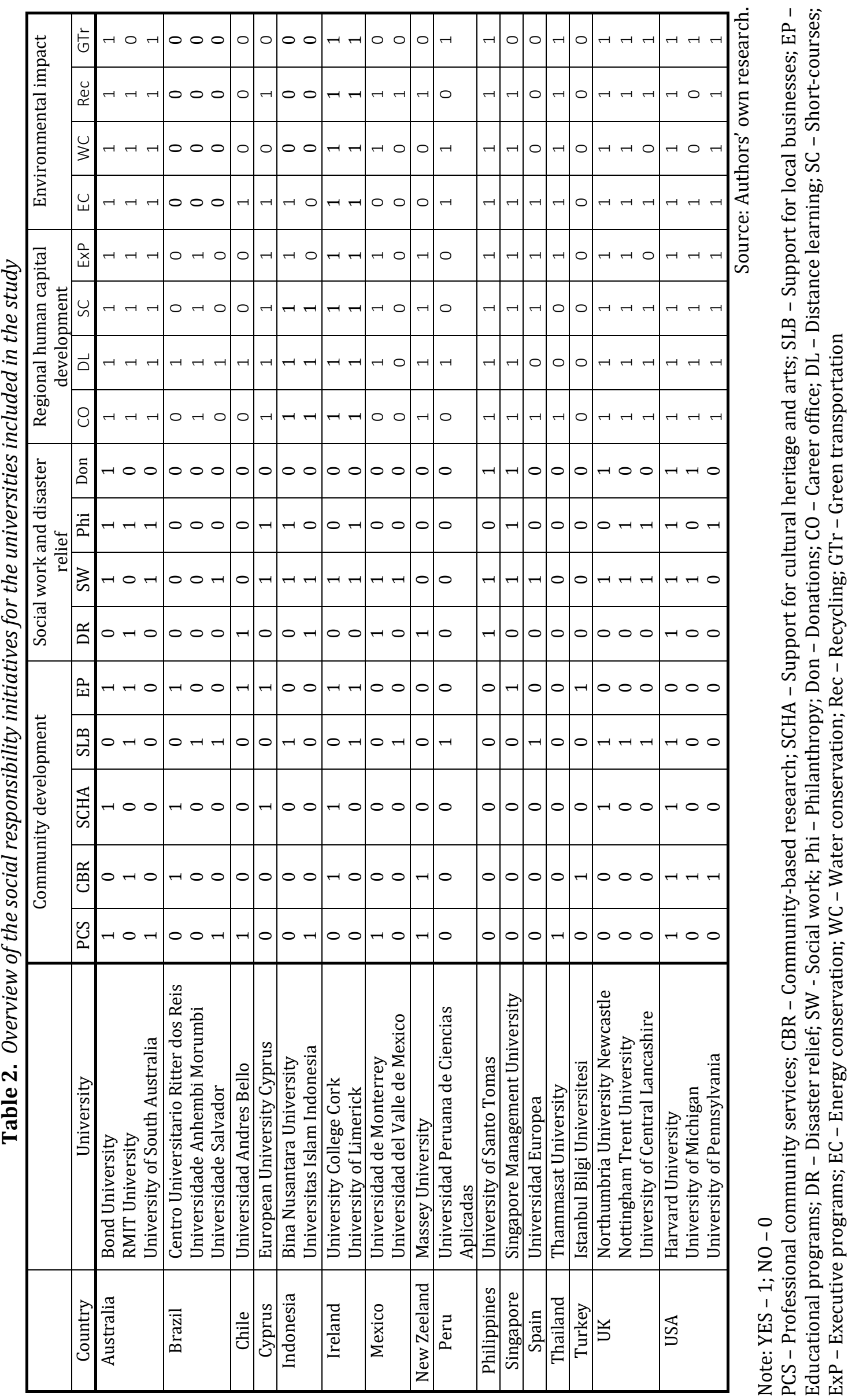


Moreover, the Universidad del Valle de Mexico (www.universidaduvm.mx) has set up a micro-enterprise "Chiltepetl Sazonador Artesanal" through which it offers guidance to Mexican women from rural areas who produce food with local ingredients on how to set up their businesses, how to identify the appropriate markets and also funding for the construction of production facilities. This initiative not only helps bring communities closer, prevents migration and increases the quality of life, but it also empowers women and transforms them into important contributors to the development of their communities.

In what regards educational programs for the local community, almost all universities included in our study have programs which link university students with local high-schools in order to help younger students improve their chances for going to university and also provide them with healthy alternatives for spending their free time. For example, universities such as Istanbul Bilgi Universitesi (www.bilgi.edu.tr) from Turkey open up their sports facilities to young people and offer free sports lessons. Moreover, universities teach local communities how to live healthier lives as in the case of the Singapore Management University (www.smu.edu.sg) in Indonesia which initiated a program for the promotion of the urban farming movement in order to help residents grow their own food or sell it locally to obtain extra revenues. Lastly, universities also help local communities with their skills development in order to increase their quality of life and prevent migration through specialized courses such as those offered by the Bilgi Universitesi (www.bilgi.edu.tr), which target vulnerable groups at risk of poverty by offering trainings on communication, self-expression, and abilities development.

\section{Social work and disaster relief}

Universities act also as catalysts for the social initiatives of other social actors, such as when they do charity work (volunteering, philanthropy and in-kind donations) and disaster relief (as support for public authorities' actions) (Table 2). Several of the universities included in our study have centers for disaster research such as the Harvard Humanitarian Initiative (hhi.harvard.edu), the RMIT Disaster Research Network (www.rmit.edu.au) or the Center for High Impact Philanthropy at the University of Pennsylvania (www.upenn.edu). However, it is not necessary for a university to have a vested research interest in disaster relief in order for it to act in a socially responsible manner as proven by the case of the Universidad Andres Bello (www.unab.cl) in Chile. In 2014 more than 2,000 volunteers from the university gathered supplies for the families impacted by the Valparaiso fire and many of them also helped with the reconstruction of the houses that were destroyed.

Moreover, many of the universities included in our study offer ongoing support for the students and staff members looking for opportunities to connect with local community organizations. They also help with looking for volunteers, funding for expenses incurred while volunteering and providing information on how to choose a social issue and how to mobilize people in order to solve it. For example, at the University of Michigan (www.umich.edu), students can take advantage of the SERVE program which offers them the necessary resources in order to enable them to form communities to solve social issues and learn from their service and activism. 
Moreover, through the Connect to Community program, the University of Michigan offers students the possibility to volunteer in numerous community organizations, the same as in the case of the Community Connect program at the University of South Australia (www.unisa.edu.au). At the University of Limerick (www.ul.ie) in Ireland social work is not only fostered through Access-Campus, but students who are active citizens and volunteer in their communities are also eligible for the President's Volunteer Award.

In what regards philanthropy, the universities either foster fundraising events and activities organized by their students, alumni and faculty or they encourage work place donations through online organizational platforms that connect their employees with various non-profit organizations carefully selected by the university staff. For example, at Bond University (bond.edu.au) in Australia students organize the yearly 'Do It in a Dress' fundraising campaign to support OneGirl's programs in West Africa through which they improve access to education for young girls. At Harvard University (www.harvard.edu), all staff members can choose to donate to a charity from a curated list and to set their pledges using the Harvard Community Gifts platform which allows the university to deduct the donation directly from the paycheck. Besides directly raising funds for numerous non-profit organizations, universities also use their knowledge and research expertise to help other fundraising campaign and donors achieve their intended goals.

Besides raising money for social issues, universities also encourage the organization of campaigns of in-kind donations and they also donate equipment to local non-profit organizations. Bond University (bond.edu.au) in Australia, for example, donates IT equipment to a local community legal center, whereas Harvard's Haitian fund (hms.harvard.edu) is helping Harvard employees with family members in Haiti. The University of Michigan Athletic Department (www.umich.edu) donates each year gear and equipment to numerous non-profit organizations from the local community. Moreover, the students at the Northumbria University at Newcastle (www.northumbria.ac.uk) in UK raise food for the local food bank in order to help those in need. They have also donated their unwanted items to be sold in support of the fight against heart disease run at the British Heart Foundation.

\section{Regional human capital development}

The primary mission of all universities has remained that of providing educational services for their students (traditional and non-traditional) and of ensuring that these services prepare graduates for the labor market. However, besides providing their students with the necessary technical knowledge and skills, universities take a more proactive approach in regards to student employability and they offer their students support in beginning their career through advice regarding job interviews, opportunities of employment and internship in the region. Moreover, in order to contribute to the regional human capital development, universities provide also lifelong learning opportunities, either as stand-alone courses (usually offered through online platforms) or as executive programs for those looking to develop their careers after entering the job market (Table 2).

All of the universities included in our study have a career office through which

they, first of all, provide students with advice regarding career choices, writing

Vol. 12, No. 4, Winter, pp. 551-570 ISSN 1842-0206 | Management\& Marketing. Challenges for the Knowledge Society 
applications, job interviews and CV preparation, and, second of all, offer them opportunities for employment or internship in the region through the partnerships that the university has set up with businesses, non-profit organizations and even public entities. These career offices usually have a central online platform where all the employment/internship offers are listed, but they also periodically organize fairs, conferences and workshops in order to enable students to network and meet industry professionals. These services are usually targeted at students from the region and provide job opportunities in the same region or country as the university, but there are also some universities which have special programs offering international internships or jobs.

In what regards lifelong learning, Harvard University (www.harvard.edu) stands out for having embraced the concept in its entirety and having created various opportunities for people of all ages to improve their skills and knowledge through online courses, professional development programs and various executive education programs offered by its faculties. Harvard has also a special learning program for people who are retired which offers them the opportunity of peer-learning through the Harvard Institute for Learning in Retirement (hilr.harvard.edu/). RMIT University (www.rmit.edu.au) in Australia offers short courses that allow people to improve their skills, meet experts in their field and access the latest knowledge and equipment. Almost all of the other universities included in our study have at least one type of initiative dedicated to lifelong learning.

\section{Environmental impact}

Another facet of university social responsibility is related to the protection of the environment and minimizing the degree of pollution and resources consumption generated by university activities. In this respect, we have looked at the ways in which top universities manage their environmental footprint through energy and water conservation, recycling and sustainable transportation practices (Table 2). Besides ensuring the sustainability of the local communities, these initiatives enable universities to use their financial resources more effectively and become stewards for environmental protection. Energy conservation and recycling initiatives are the most popular among the universities included in our study, whereas green transportation is the least popular, with less than half of the universities having policies and programs for the support of environmentally friendly means of transportation.

When it comes to their environmental impact, universities are placing a particular emphasis on energy conservation, energy efficiency, and finding alternative sources of energy. Since 2006, Harvard University (www.harvard.edu) has implemented more than 100 energy conservation measures which allowed it to decrease its carbon footprint by over 7,000 metric tons and also to reduce its administrative costs by more than $\$ 1$ million. RMIT (www.rmit.edu.au) plans to reduce its greenhouse gas emissions by $25 \%$ till 2020 and to achieve this goal it has invested in building upgrades, energy efficiency technology and the purchase of carbon offsets. Moreover, they are considering initiating an educational program to help modify the behavior of staff and students and teach them to switch off the lights and equipment at the end of the day. The University of Michigan (www.umich.edu) has such a program, called Sustainable Workplace Certification Program which is

Vol. 12, No.4, Winter, pp. 551-570 ISSN 1842-0206 | Management \& Marketing. Challenges for the Knowledge Society 
available to all university employees interested to learn how to reduce energy consumption and the amount of waste produced.

Besides energy, universities are also growingly concerned about their high usage of water resources and have implemented various programs for water conservation. Australia has a very dry climate and water conservation is a major national concern, which is why RMIT (www.rmit.edu.au) has installed various water saving technologies including grey water recycling, rainwater harvesting and drought tolerant landscaping. Moreover, University of South Australia (www.unisa.edu.au) commenced its water conservation programs as early as 2002 and it managed to dramatically reduce its consumption of potable water by seeking recycled nonpotable water sources for uses within buildings and irrigation and rain water harvesting. Besides finding alternative water sources, universities also strive to limit the quantity of water used in their buildings by identifying leaks in the water system and replacing bathroom faucets and urinals with more water efficient ones as in the case of the University College Cork (www.ucc.ie).

In what regards recycling initiatives, the most common recycled waste types are paper and cardboard, general waste, batteries, e-waste, fluorescent tubes, plastic, and metals. At Massey University in New Zealand (www.massey.ac.nz) students are not only invited to recycle their waste in order to minimize the use of resources, but they are also offered the opportunity to research matters of recycling and help the local administration implement recycling programs throughout the city through the intermediation of the Zero Waster Research and Development project in partnership with the local council.

In matters related to transportation, universities encourage the use of public transportation and environmentally friendly cars and also carpooling or car sharing in order to reduce the carbon footprint created by staff, faculty members and students. University of Limerick (www.ul.ie) in Ireland has been recognized for its efforts to promote alternative travel modes such as walking, cycling, public transportation and car-sharing. The university has invested both in upgrading its physical infrastructure to accommodate these travel modes and spent also resources on educational programs. At the University of Pennsylvania (www.upenn.edu) students receive a PenPass which is a heavily subsidized pass for buses and subways. The university also allocates preferred parking for carpoolers and launched a green rate parking permit for environmentally friendly cars in 2010. Moreover, universities also invest in their own fleets of environmentally friendly cars such as in the case of the University of South Australia (www.unisa.edu.au) which owns 12 vehicles, while also planting trees to offset the other car's carbon emissions through the Greenfleet Vehicle program.

\section{Factor analysis findings}

Factor analysis was used to identify underlying variables, or factors, that explain the patterns of correlations within a set of observed variables (Yong and Pearce, 2013), in our case social responsibility initiatives of universities. The method of factor extraction employed in the paper is Principal Component Analysis. We took into consideration seventeen variables grouped in four categories which explain the types of social responsibility activities in which the universities engage. The descriptive statistics for the group of variables is shown in Table 3. The Cronbach's Alpha score 
for these variables is 0.754 , over 0.7 , meaning that the reliability requirements of the analysis are met.

Table 3. Descriptive statistics

\begin{tabular}{|l|l|r|r|}
\hline \multicolumn{1}{|c|}{ Categories } & \multicolumn{1}{|c|}{ Social responsibility initiatives } & Mean & Std. Deviation \\
\hline Community development & Professional community services & 0.33 & 0.480 \\
& Community-based research & 0.30 & 0.465 \\
& Support for cultural heritage and arts & 0.22 & 0.424 \\
& Support for local businesses & 0.44 & 0.506 \\
Social work and disaster relief & Educational programs & 0.33 & 0.480 \\
& Disaster relief & 0.26 & 0.447 \\
\cline { 2 - 4 } & Social work & 0.67 & 0.480 \\
Regional human capital & Philanthropy & 0.41 & 0.501 \\
development & Donations & 0.22 & 0.424 \\
& Career office & 0.74 & 0.447 \\
Environmental impact & Distance learning & 0.85 & 0.362 \\
& Short-courses & 0.74 & 0.447 \\
& Executive programs & 0.70 & 0.465 \\
& Energy conservation & 0.70 & 0.465 \\
& Water conservation & 0.52 & 0.509 \\
& Recycling & 0.63 & 0.492 \\
& Green transportation & 0.48 & 0.509 \\
\hline
\end{tabular}

Source: Authors' own research.

Table 3 shows that $82 \%$ of the variables included in the study have a mean score $\geq 0.3$ and almost half $(47 \%)$ have a mean score above the middle point, which means that they highly account for a better university rating in social responsibility. Also, the standard deviation for $76.47 \%$ of our variables is lower than the middle point, meaning that the values in the statistical data set are close to the mean of the data set, on average and, therefore, these variables are highly reliable. Social responsibility actions that might contribute at a broader extent to university ranking include: distance-learning, career office, short-courses, executive programs, energy conservation, social work, recycling, and water conservation. For further analysis we excluded the variables with a mean score $<0.3$ (in our case, three variables) since anything lower would suggest a really weak relationship between the variables (Tabachnick and Fidell, 2007). An exploratory factor analysis was employed for remaining group of variables which describe different types of social responsibility initiatives. The main outputs of a factor analysis were correlation matrix and communalities. Correlation matrix helps identifying the pattern of relationships between the variables examined, whilst communalities indicate the amount of variance in each variable that is accounted for, before and after extraction (Stevens, 2012).

The correlation matrix for the group of selected social responsibility initiatives is presented in Table 4. This output helps us determine if our dataset is suitable for exploratory factor analysis by checking if there is a patterned relationship amongst our variables. The Pearson correlation analysis revealed that there are several variables with large number of low correlation coefficient $(r<+/-0.30)$, which should be removed as they indicate a lack of patterned relationships. A new exploratory factor analysis has been employed for the ten variables extracted: social work, philanthropy, career office, distance learning, short-courses, executive programs, 
energy conservation, water conservation, recycling, and green transportation. The correlation matrix is presented in Table 5. The Pearson correlation analysis revealed this time that there are medium to strong correlations amongst the variables that remained in the study.

Table 4. Inter-item correlation matrix for social responsibility initiatives (14 variables)

\begin{tabular}{|c|c|c|c|c|c|c|c|c|c|c|c|c|c|c|}
\hline & \multicolumn{14}{|c|}{ Correlation matrix } \\
\hline & PCS & CBR & SLB & EP & SW & Phi & $\mathrm{CO}$ & $\mathrm{DL}$ & SC & ExP & $\mathrm{EC}$ & WC & $\operatorname{Rec}$ & GTr \\
\hline $\begin{array}{r}\text { Professional } \\
\text { community services }\end{array}$ & 1 & -.115 & -.316 & -.167 & & -.107 & -.120 & .074 & -.120 & -.057 & -.229 & .052 & .054 & -.052 \\
\hline $\begin{array}{r}\text { Community-based } \\
\text { research }\end{array}$ & & 1 & -.254 & .229 & -.401 & -.043 & .014 & .042 & .014 & .066 & -.112 & -.024 & -.006 & .024 \\
\hline $\begin{array}{r}\text { Support for local } \\
\text { businesses }\end{array}$ & & & 1 & -.316 & .158 & .169 & .019 & -.047 & .019 & -.073 & .091 & -.033 & -.086 & .033 \\
\hline Educational programs & & & & 1 & -.167 & .213 & -.120 & .074 & -.120 & -.057 & .115 & .052 & .054 & -.210 \\
\hline Social work & & & & & 1 & .267 & .299 & 147 & .478 & .229 & .229 & .105 & .271 & .201 \\
\hline Philanthropy & & & & & & 1 & .491 & .346 & .491 & .373 & .538 & .346 & .480 & .257 \\
\hline Career office & & & & & & & 1 & .229 & .807 & .727 & .542 & .276 & .421 & .401 \\
\hline Distance learning & & & & & & & & 1 & .467 & .186 & 186 & .224 & .112 & 193 \\
\hline Short-courses & & & & & & & & & 1 & .727 & .356 & 276 & .421 & .232 \\
\hline Executive programs & & & & & & & & & & 1 & .467 & .511 & .510 & .301 \\
\hline Energy conservation & & & & & & & & & & & 1 & .511 & .342 & .625 \\
\hline Water conservation & & & & & & & & & & & & & .642 & .632 \\
\hline $\begin{array}{r}\text { Recycling } \\
\text { Green transportation }\end{array}$ & & & & & & & & & & & & & & .432 \\
\hline & & & & & & & & & & & & & & \\
\hline
\end{tabular}

Source: Authors' own research.

Table 5. Inter-item correlation matrix for social responsibility initiatives (10 variables)

\begin{tabular}{|l|r|r|r|r|r|r|r|r|r|r|}
\hline & \multicolumn{1}{|c|}{ SW } & \multicolumn{1}{c|}{ Phil } & \multicolumn{1}{c|}{ CO } & \multicolumn{1}{c|}{ DL } & \multicolumn{1}{c|}{ SC } & ExP & EC & WC & Rec & GTr \\
\hline Social work & 1.000 & .267 & .299 & .147 & .478 & .229 & .229 & .105 & .271 & .210 \\
Philanthropy & & 1.000 & .491 & .346 & .491 & .373 & .538 & .346 & .480 & .257 \\
Career office & & & 1.000 & .229 & .807 & .727 & .542 & .276 & .421 & .401 \\
Distance learning & & & & 1.000 & .467 & .186 & .186 & .224 & .112 & .193 \\
Short-courses & & & & & 1.000 & .727 & .356 & .276 & .421 & .232 \\
Executive programs & & & & & & 1.000 & .467 & .511 & .510 & .301 \\
Energy conservation & & & & & & & 1.000 & .511 & .342 & .625 \\
Water conservation & & & & & & & & 1.000 & .642 & .632 \\
Recycling & & & & & & & & & 1.000 & .432 \\
Green transportation & & & & & & & & & & 1.000 \\
\hline
\end{tabular}

Source: Authors' own research.

The scale was tested for normality and reliability using the Bartlett Test of Sphericity and the Kaiser-Meyer-Olkin (KMO). The Bartlett test was 135.627 with a significant level of $\mathrm{p}<0.0001$. The KMO measure of sampling adequacy was 0.684 (above 0.50), these values suggesting that the data can be reliably tested using factor analysis and we do have patterned relationships amongst the variables. Another way to check if our data is suitable for exploratory factor analysis is by looking at the diagonal element of the Anti-Image Correlation matrix that has the 'a' superscript, as measure of sampling adequacy, above 0.50 (Table 6). The values obtained in our case suggest that the data can be reliably tested using factor analysis.

We further looked at the Communalities and Total Variance Explained data (see Tables 7 and 8) to determine the number of significant factors. The Varimax with Kaizer Normalization rotation method, using eigenvalue greater than one, revealed 
two significant factors --social work and regional human capital development and environment impact-- that accounted for $59.86 \%$ of the variance of the original variables. The eigenvalue represents the total of variance explained by one factor. Any factor that has an eigenvalue less than one does not have enough total variance explained to represent a unique factor and it is, therefore, disregarded.

Table 6. Anti-image correlation

\begin{tabular}{|l|r|r|r|r|r|r|r|r|r|r|}
\hline & SW & \multicolumn{1}{c|}{ Phi } & \multicolumn{1}{c|}{ CO } & \multicolumn{1}{c|}{ DL } & \multicolumn{1}{c|}{ SC } & EP & EC & WC & Rec & GTr \\
\hline Social work & $.545^{\mathrm{a}}$ & -.008 & .304 & .224 & -.514 & .154 & -.161 & .164 & -.145 & -.185 \\
Philanthropy & -.008 & $.734 \mathrm{a}$ & -.124 & -.207 & -.093 & .222 & -.459 & -.040 & -.365 & .296 \\
Career office & .304 & -.124 & $.691 \mathrm{a}$ & .292 & -.621 & -.260 & -.257 & .383 & -.085 & -.384 \\
Distance learning & .224 & -.207 & .292 & $.486^{\mathrm{a}}$ & -.554 & .210 & -.001 & -.132 & .202 & -.167 \\
Short-courses & -.514 & -.093 & -.621 & -.554 & $.655^{\mathrm{a}}$ & -.392 & .245 & -.013 & -.019 & .174 \\
Executive programs & .154 & .222 & -.260 & .210 & -.392 & $.762^{\mathrm{a}}$ & -.207 & -.430 & -.086 & .294 \\
Energy conservation & -.161 & -.459 & -.257 & -.001 & .245 & -.207 & $.730^{\mathrm{a}}$ & -.167 & .296 & -.371 \\
Water conservation & .164 & -.040 & .383 & -.132 & -.013 & -.430 & -.167 & $.668^{\mathrm{a}}$ & -.448 & -.472 \\
Recycling & -.145 & -.365 & -.085 & .202 & -.019 & -.086 & .296 & -.448 & $.763^{\mathrm{a}}$ & -.113 \\
Green transportation & -.185 & .296 & -.384 & -.167 & .174 & .294 & -.371 & -.472 & -.113 & $.645^{\mathrm{a}}$ \\
\hline
\end{tabular}

a. Measures of Sampling Adequacy (MSA)

Source: Authors' own research.

Table 7. Communalities for social responsibility initiatives

\begin{tabular}{|l|r|r|}
\hline & Initial & Extraction \\
\hline Social work & 1.000 & .322 \\
Philanthropy & 1.000 & .477 \\
Career office & 1.000 & .737 \\
Distance learning & 1.000 & .259 \\
Short-courses & 1.000 & .909 \\
Executive programs & 1.000 & .636 \\
Energy conservation & 1.000 & .610 \\
Water conservation & 1.000 & .781 \\
Recycling & 1.000 & .559 \\
Green transportation & 1.000 & .696 \\
\hline
\end{tabular}

Extraction Method: Principal Component Analysis

Source: Authors' own research.

Table 8. Total variance explained for social responsibility initiatives

\begin{tabular}{|l|r|r|r|r|r|r|}
\hline \multirow{2}{*}{ Component } & \multicolumn{3}{|c|}{ Initial Eigenvalues } & \multicolumn{2}{c|}{ Extraction Sums of Squared Loadings } \\
\cline { 2 - 7 } & Total & \% of Variance & Cumulative \% & Total & \% of Variance & Cumulative \% \\
\hline & 4.601 & 46.008 & 46.008 & 4.601 & 46.008 & 46.008 \\
3 & 1.385 & 13.854 & 59.862 & 1.385 & 13.854 & 59.862 \\
4 & .950 & 9.495 & 69.357 & & & \\
5 & .848 & 8.476 & 77.833 & & & \\
6 & .768 & 7.682 & 85.515 & & & \\
7 & .683 & 6.826 & 92.341 & & & \\
8 & .361 & 3.615 & 95.956 & & & \\
9 & .193 & 1.929 & 97.884 & & & \\
10 & .128 & 1.281 & 99.165 & & & \\
\hline
\end{tabular}

Extraction Method: Principal Component Analysis

Source: Authors' own research.

The rotated factor loadings are shown in the Rotated Factor Matrix (see Table 9). As illustrated in the table, using rotation and suppressing small coefficients help 
with the interpretation. The factor loadings show that our factors are fairly desirable with at least four variables per factors that are above .50 .

Table 9. Rotated factor matrix

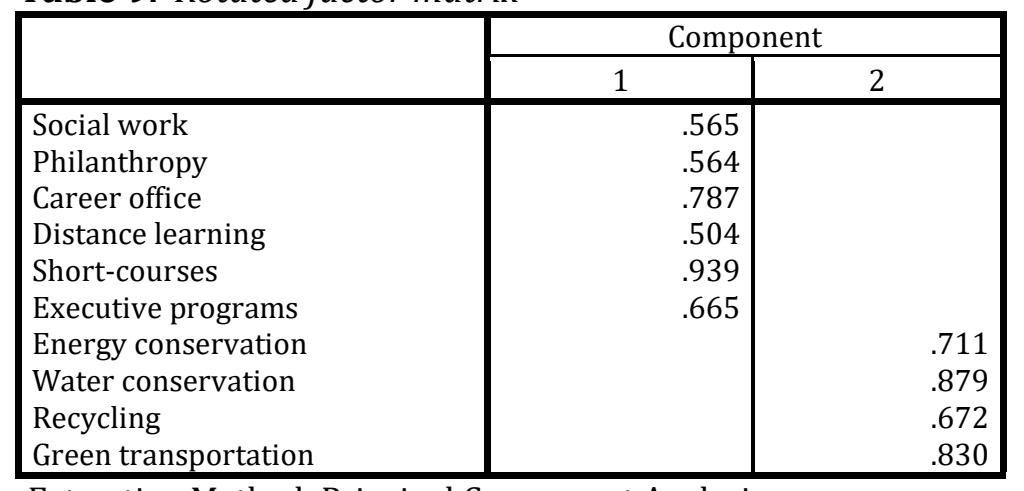

Extraction Method: Principal Component Analysis

Rotation Method: Varimax with Kaiser Normalization. a. Rotation converged in 3 iterations

Source: Authors' own research.

Factor 1 (Cronbach's Alpha=0.812) includes six components, which are variables suggesting a strong desire of universities to demonstrate social responsibility through social work and regional human capital development: social work, philanthropy, career office, distance learning, short-courses, and executive programs. Factor 2 (Cronbach's Alpha=0.820) includes four components, which are variables directly linked to the university's environmental concern and impact: energy conservation, water conservation, recycling and green transportation.

The results of our analysis confirmed partially the first hypothesis and entirely the second hypothesis. Thus, all of the universities included in the study demonstrate a high level of involvement and participation in various social responsibility actions (Table 2). A high intensity of the social responsibility activities, as well as their broad diversity will ensure a high university rating in social responsibility, which is true considering that $92.59 \%$ of the universities included in the study were rated as 5 stars in social responsibility. Also, a high ranking in social responsibility doesn't necessary lead to better overall ranking of universities, which means that other criteria impact more significantly the global ranking of universities (Daraio et al., 2015; Marconi and Ritzen, 2015; Păunescu, 2017). Moreover, the results of our research confirmed the second hypothesis. There are two 'meaningful' factors that can produce correlation amongst the different types of social responsibility activities of a university and that influence to a wide extent the intensity with which universities engage in social responsibility initiatives.

\section{Conclusion}

The paper aimed to identify and understand various initiatives taken by top universities worldwide, best ranked by QS Stars, to demonstrate social responsibility. Thus, it scrutinized and discussed the university obligations to society by analyzing 27 world universities best ranked in social responsibility according to QS Stars University Rating 2016. The four types of university social responsibility analyzed in the paper were: community investment and development, social work and disaster 
relief, regional human capital development, and environmental impact. In the paper, through community investment and development we understand benefits gained by the communities served by universities, social work and disaster relief refers to charity work that contributes to development of the communities, regional human capital development measures employability, skills developed and jobs created in the communities served by universities, whilst environmental impact assesses interest in programs like energy conservation, water conservation, waste minimization, recycling, and green transportation. The following social responsibility actions and initiatives have been identified and exemplified for the sample universities: professional community services, community-based research, support for cultural heritage and arts, support for local businesses, educational programs, disaster relief programs, social work, philanthropy, donations, career office, distance learning, shortcourses, executive programs, energy and water conservation programs, recycling, and green transportation programs.

Our results suggest that the level of involvement in social responsibility actions is high for all the universities included in the study. Also, the types of initiatives vary in terms of nature, intensity and impact for each one of the dimensions investigated. The extent to which universities included in the study demonstrate social responsibility is strongly influenced by their focus on activities related to social work and regional human capital development, as well as environmental impact. Our results are consistent with Jongbloed et al.'s (2008) findings which argued on the need for higher education institutions to enter into close working relationships with multiple actors on various levels, including government agencies, students, business, research sponsors, communities and regional authorities. Community engagement is also given a high priority in Irazábal et al.'s (2015) research findings. Moreover, Pucciarelli and Kaplan (2016) also emphasized the need to expand interactions and value co-creation with key stakeholders.

The research findings offer good insights for both universities' leaders and community developers in their efforts to develop strategies for growing a prosperous community. The main limitations of the paper arise from the scarcity of the data available on the official webpages of the universities included in the study, regarding the social responsibility activities in which they engage. Also, another limitation may arise from the sample size. However, the results proved to be statistically significant for our sample universities and, therefore, highly reliable for those higher education institutions' leaders and communities' developers interested to develop strategies for reinforcing the academia-community partnership.

\section{Disclaimer}

A shorter version of this article was presented during the 11th International Conference on Business Excellence (ICBE) "Strategy, Complexity and Energy in changing times", March 30-31, 2017, Bucharest, Romania, and published in the conference proceedings. 


\section{References}

Afshar, A. (2005), "Community-campus partnerships for economic development: community perspectives", Federal Reserve Bank of Boston, Discussion Papers. Retrieved from http://www.bos.frb.org/commdev/pcadp/2005/pcadp0502.pdf (Accessed on January 10, 2017).

Amaral, A. and Magalhães, A. (2002), "The emergent role of external stakeholders in European higher education governance", In: Governing Higher Education: National Perspectives on Institutional Governance, pp. 1-21.

Bender, G. (2008), "Exploring conceptual models for community engagement at Higher Education Institutions in South Africa", Perspectives in Education, Vol. 26, No. 1, pp. 81-95.

Benneworth, P. and Sanderson, A. (2009), "The regional engagement of universities: building capacity in a sparse innovation environment", Higher Education Management and Policy, Vol. 21, No. 1, pp. 1-18.

Bernardo, M.A.C., Butcher, J. and Howard, P. (2012), "An international comparison of community engagement in higher education", International Journal of Educational Development, Vol. 32, No. 1, pp. 187-192.

Boyer, E.L. (1996), "The scholarship of engagement", Journal of Public Services \& Outreach, Vol. 1, No. 1, pp. 11-20.

Boyle, M.E. and Silver, I. (2005), "Poverty, partnerships, and privilege: Elite institutions and community empowerment", City and Community, Vol. 4, No. 3, pp. 233-253.

Callon, M. and Rabeharisoa (2003), "Research 'in the wild` and the shaping of new social identities", Technology in Society, Vol. 25, No. 2, pp. 193-204.

Clark, R.E. (1998), "Supported employment and managed care: Can they coexist?", Psychiatric Rehabilitation Journal, Vol. 22, No. 1, pp. 62-68.

Checkoway, B. (1995), "Six strategies of community change", Community Development Journal, Vol. 30, pp. 2-20.

Daraio, C., Bonaccorsi, A., Simar, L. (2015), "Rankings and university performance: A conditional multidimensional approach", European Journal of Operational Research, Vol. 244, No. 3, pp. 918-930.

De Boer, H.F., Enders, J. and Leisyte, L. (2007), "Public sector reform in Dutch higher education: The organizational transformation of the university", Public Administration, Vol. 85, No. 1, pp. 27-46.

Dima, A.M., Vasilache, S., Ghinea, V. and Agoston, S. (2013), "A model of academic social responsibility", Transylvanian Review of Administrative Sciences, No. 38, pp. 23-43.

D’Este, P. and Patel, P. (2007), “University-industry linkages in the UK: What are the factors underlying the variety of interactions with industry?", Research Policy, Vol. 36, No. 9, pp. 1295-1313.

Dudian, M. (2011), "Innovative clusters. The case of Romania", Management Research and Practice, Vol. 3, No. 3, pp. 1-11.

Ercsey, I. (2017), "The role of customers' involvement in value co-creation behavior. Is value co-creation the source of competitive advantage?", Journal of Competitiveness, Vol. 9, No. 3, pp. 51-66. 
Etzkowitz, H. and Viale, R. (2010), "Polyvalent Knowledge and the Entrepreneurial University: A Third Academic Revolution?”, Critical Sociology, Vol. 36, No. 4, pp. 595-609.

Farrar, M. and Taylor, R. (2009), "University-community engagement”, In: Denton, S., Brown, S. (Eds.), A Practical Guide to University and College Management. Beyond Bureaucracy, Routledge, New York, pp. 247-265.

Goldberg-Freeman, C., Kass, N., Gielen, A.C. and Farfel, M. (2010), "Faculty beliefs, perceptions, and level of community involvement in their research: A survey at one urban academic institution", Journal of Empirical Research on Human Research Ethics, Vol. 5, No. 4, pp. 65-76.

Hammersley, L. (2013), “Community-based service-learning: Partnerships of reciprocal exchange?", Asia-Pacific Journal of Cooperative Education, Vol. 14, No. 3, pp. 171-184.

Irazábal, C., Mendoza-Arroyo, C., Arciniegas, C.O., Sánchez, R.O. and Maya, J. (2015), "Enabling community - higher education partnerships: common challenges, multiple perspectives", Current Opinion in Environmental Sustainability, Vol. 17 , pp. 22-29.

Janiunaite, B. and Gudaityte, D. (2007), "Higher education as an agent of social innovation", In: Higher education and national development. Universities and societies in transition. Routledge, Oxon, pp. 215-226.

Jongbloed, B., Enders, J. and Salerno, C. (2008), "Higher education and its communities: Interconnections, interdependencies and a research agenda", Higher Education, Vol. 56, No. 3, pp. 303-324.

Klekovski, S., Krzalovski, A., Sazdovska, S., Jakovleska, G., Kolic, M. and Stojanova, D. (2009), "Social responsibility of citizens", Macedonian Centre for International Cooperation, Skopje.

Kruss, G. (2012), "Reconceptualising engagement: a conceptual framework for analyzing university interaction with external social partners", South African Review of Sociology, Vol. 43, No. 2, pp. 5-26.

Laredo, P. (2007), “Towards a third mission for Universities”, [Online] Retrieved from: http://portal.unesco.org/education/en/files/53913/11858787305Towards_a_th ird_Mission_universities.pdf/Towaards_a_third_Mission_universities.pdf (Accessed 12 November 2016).

Marconi, G., Ritzen, J. (2015), "Determinants of international university rankings scores", Applied Economics, Vol. 47, No. 57, pp. 6211-6227.

Mtawa, N.N., Fongwa, S.N. and Wangenge-Ouma, G. (2016), "The scholarship of university-community engagement: Interrogating Boyer's model", International Journal of Educational Development, Vo. 49, No. C, pp. 126-133.

Muller, J. and Subotzky, G. (2001), "What knowledge is needed in the new millennium?", Organization, Vol. 8, No. 2, pp. 163-182.

Păunescu, C. (2017), „Does community service make any difference in university rankings?", Lecture Notes in Business Information Processing, Vol. 279, pp. 283294.

Păunescu, C., Găucă, O. and Drăgan, D. (2017), “Managing obligations to society. Case of best ranked universities in social responsibility", Proceedings of the International Conference on Business Excellence, Vol. 11, No. 1, pp. 818-825. 
Păunescu, C. and Cantaragiu, R. (2015), „The social role of university entrepreneurship", In: Economics: Concepts, Methodologies, Tools, and Applications, Vol. 2-3, pp. 1055-1071.

Philpott, K., Dooley, L., O'Reilly, C., and Lupton, G. (2011), "The entrepreneurial university: examining the underlying academic tensions", Technovation, Vol. 31, pp. 161-170.

Pucciarelli, F. and Kaplan, A. (2016), "Competition and strategy in higher education: Managing complexity and uncertainty", Business Horizons, Vol. 59, No. 3, pp. 311320.

Sporn, B. (1999), Adaptive university structures, Jessica Kingsley Publishers, London.

Stevens, J. P. (2012), Applied multivariate statistics for the social sciences, the $5^{\text {th }}$ edition, Routledge, London.

Sullivan, M., Kone, A., Senturia, K.D., Chrisman, N.J., Ciske, S.J. and Krieger, J.W. (2001), "Researcher and researched-community perspectives: Toward bridging the gap", Health Education \& Behavior, Vol. 28, No. 2, pp. 130-149.

Tabachnick, B.G. and Fidell, L.S. (2007), Using multivariate statistics, the 5th edition, Allyn \& Bacon, Boston.

Vasile, D., Vulturescu, V., Pavelescu, L.C. and Dudian, M. (2015), "Romania's participation to the 7th EU Framewok Programme", Industria Textilă, Vol. 66, No. 4, pp. 226-231.

Weerts, D.J. and Sandmann, L.R. (2008), "Building a two-way street: challenges and opportunities for community engagement at Research Universities", Review of Higher Education, Vol. 32, No. 1, pp. 73-106.

Yong, A.G. and Pearce, S. (2013), "A beginner's guide to factor analysis: Focusing on exploratory factor analysis", Tutorials in Quantitative Methods for Psychology, Vol. 9, No. 2, pp. 79-94. 